\title{
Premarital Sex among Adolescent Street Children in Pekanbaru
}

\author{
Yessi Harnani ${ }^{1}$, Agus Alamsyah ${ }^{2}$, Alhidayati $^{3}$ \\ ${ }^{1}$ Quality Assurance Center Hang Tuah Pekanbaru Riau, Indonesia \\ ${ }^{2}$ Research Center and Dedication Hang Tuah Pekanbaru, Riau, Indonesia \\ ${ }^{3}$ Public Health School Hang Tuah Pekanbaru, Riau, Indonesia
}

\begin{tabular}{l}
\hline Article Info \\
\hline Article history: \\
Received Jan 19, 2018 \\
Revised Mar 12, 2018 \\
Accepted Mar 25, 2018 \\
\hline
\end{tabular}

\section{Keyword:}

Premarital sex

Street children

Status girlfriend

The city of Pekanbaru

\begin{abstract}
Premarital sex is any behavior that is driven by sexual desire with the opposite sex before marriage. Some premarital sex activities include feeling, kissing, necking, petting, and intercourse. Premarital sex in adolescents has a negative impact such as unwanted pregnancy, unsafe abortion, resulting in increased maternal, neonatal deaths and perinatal, increasing the incidence of HIV / AIDS, dropping out of school. Quantitative analytical observational method with cross sectional design. Samples of 100 teenage children street children in Pekanbaru City. Snow ball sampling technique, Instrument is a questionnaire. Univariate data analysis, multivariate bivariate with logistic regression test. Results showed 65\% (65 people) prenup sex, $78 \%$ dating, $74 \%$ pornography exposure, peer influence $70 \%$, lack of knowledge of youth $61 \%$, family not harmonious $80 \%$, and low parental supervision $57 \%$. The related variables ( $\mathrm{p}$ value $<0.05$ ) with premarital sex behavior are boyfriend status, pornographic exposure and peer influence. Status girlfriend most risky 39 times premarital sex. Conclusion there is relationship and influence of 3 factors to premarital sex on adolescent child of Street of Pekanbaru Town. Suggestions for the formation of containers such as peer counselor and BKR (Youth Family Development) as a precautionary measure to increase the number of premarital sex incidents in the juveniles Street Children Pekanbaru.
\end{abstract}

Copyright $@ 2018$ Institute of Advanced Engineering and Science. All rights reserved.

\section{Corresponding Author:}

Yessi Harnani,

Quality Assurance Center Hang Tuah Pekanbaru,

Riau, Indonesia.

Email: yessiharnani@gmail.com

\section{INTRODUCTION}

Street children are a real phenomenon part of life that causes complex social problems. The existence of street children is often ignored and not. Their filthy appearance, coming from poor families, their slum settlements or even they have no place to live [1]. The existence of street children is already commonly seen in major cities in Indonesia. Generally street children work in the informal sector, ie as scavengers, policemen, garbage collector, car carpenters, hawkers, beggars, parking attendants, and other money-making jobs [2].

Based on data from UNICEF (United International International Emergency Fund), the number of street children in the world in 2008 reached 100 million children.In 2002, based on the results of Susenas held by BPS \& Pusdatin Ministry of Social as many as 94,674 street children in Indonesia.Terjadi increase 64 $\%$ of street children from 2002 - 2008 or an average of about $10.6 \%$ per year increase. Using estimates with a very conservative approach will increase by $10.6 \%$ per year for street children, and then by the end of 2015 there are estimated to be three hundred thousand street children in Indonesia [3].

The phenomenon of street children that occur in urban areas is very interesting to be observed, especially the effects on sexual behavior that may arise. The trend of free living on the streets has an impact 
on sexual behavior among street children. Sexual behavior is the initial trigger for the emergence of groups of street children who are vulnerable to the occurrence of unwanted pregnancies, abortion, sexually transmitted infections (STIs) and HIV / AIDS infections [4].

According Karyati, if free sex on street children continues to be left it will have a bad effect such as unwanted pregnancy, abortion, marriage and early pregnancy, sexually transmitted diseases and Human Immuno Deficiency Virus / Acquired Immuno Deficiency Syndrome or HIV / AIDS [4]. Adolescents aged 15-29 years are vulnerable to HIV / AIDS infected by the effects of promiscuity and the use of injecting needles. Pekanbaru City which consists of 12 districts has experienced a lot of progress so invite many people to live and try to live in it. According to data Central Bureau of Statistics, the population of Pekanbaru City reached 943,961 thousand in 2012. This rapid development caused the problem social, one of which is the problem of street children [1],[5].

The number of street children in Pekanbaru City based on the Social Service and Funeral in 2015 amounted to more than 150 children. From the data collection in the six points there are 150 children working on the streets. The six areas recorded in KPAID are at Simpang Mal Ska (Kecamatan Tampan), Simpang Gramedia (Pekanbaru Town), Simpang Jalan Harapan Raya-Sudirman (Bukit Raya Sub-district), Simpang Pasar Pagi Arengka (Marpoyan Damai Sub-district), Ramayana Pasar Kodim (Pekanbaru Kota) and Simpang Jl Riau-Jl Yos Sudarso (Kecamatan Senapelan). From the results of interviews that researchers do with the head of social affairs Pekanbaru city, that the number of street children in the city of Pekanbaru difficult to know the exact number. This is because every raid is still a lot of street children are successfully escaped, so that the existing data does not match the actual data.

The results of the initial interviews dissertation conducted by researchers on 50 teenagers street children who are in shelter homes social services found that all respondents (100\%) answered never conduct sexual behavior ranging from hand grip, hug, kiss cheek, kiss the lips, holding the breast, touching the genitals and the one that until sexual intercourse. In the abandoned house there are 2 street children who are pregnant out of wedlock and the couple live a house without a legal marriage bond. Based on the data and phenomena that occur on street children, this research is expected to be the basis of the determination of premarital sex treatment efforts with health promotion efforts in the field of reproductive health with the knowing factors causing premarital sex on street adolescent girls.

\section{RESEARCH METHOD}

This research is a quantitative analytic with cross sectional research design, implemented in Pekanbaru City in March-May Year 2017. Population in this research is juvenile street children residing in Kota Pekanbaru. Sampel research part of the population amounted to 100 respondents. The data were collected by interview using questionnaire. Analysis of univariate, bivariate and multivariate data, for independent variables (adolescent knowledge of reproductive health, girlfriend status, pornographic exposure, family harmony, peers, parental supervision) using chi square test on bivariate analysis and multiple logistic regression with prediction factor model for multivariate analysis. The data are presented in tabular form with narration.

\section{RESULTS AND ANALYSIS}

Table 1 it can be seen that variable status girlfriend, malignancies to pornography and influence their peers associated with premarital sex in adolescent street children in Pekanbaru. While variable of teenagers about reproductive health, harmonious family, supervision parents is not related with premarital sex in adolescent street children.

Table 1. Result of Bivariate Analysis

\begin{tabular}{lcccccccccccc}
\hline $\begin{array}{l}\text { Premarital } \\
\text { sex }\end{array}$ & \multicolumn{2}{c}{ girlfriend status } & \multicolumn{3}{c}{ Knowledge } & \multicolumn{2}{c}{$\begin{array}{c}\text { Pornografy } \\
\text { exposure }\end{array}$} & \multicolumn{2}{c}{$\begin{array}{c}\text { harmonious } \\
\text { family }\end{array}$} & \multicolumn{2}{c}{$\begin{array}{c}\text { Friends of the } \\
\text { same age }\end{array}$} & \multicolumn{2}{c}{$\begin{array}{c}\text { Parental } \\
\text { Control }\end{array}$} \\
& Yes & No & Low & High & Yes & No & Yes & No & Yes & No & Yes & No \\
\hline Yes & 63 & 2 & 38 & 27 & 42 & 23 & 54 & 11 & 51 & 14 & 43 & 38 \\
No & 15 & 20 & 23 & 12 & 32 & 3 & 26 & 9 & 19 & 16 & 59 & 260 \\
$\sum_{\text {P value }}$ & 78 & 22 & 61 & 39 & 74 & 26 & 80 & 20 & 70 & 30 & 102 & 298 \\
POR & $42.0(8.8-199.6)$ & $0.7(0.3-1.7)$ & $0.17(0.05-0.6)$ & $1.6(0.6-4.6)$ & $3.1(1.3-7.5)$ & $4.9(2.9-8.3)$ \\
\hline
\end{tabular}

Based on Table 2 it is known that the girlfriend status variables, pornographic exposure and peers enter into multivariate modeling candidate because they have $\mathrm{p}$ value $<0.25$. 
Table 2. Result of Multivariate Selection Criteria

\begin{tabular}{cccccc}
\hline $\begin{array}{c}\text { girlfriend } \\
\text { status }\end{array}$ & Knowledge & $\begin{array}{c}\text { Pornografy } \\
\text { exposure }\end{array}$ & $\begin{array}{c}\text { harmonious } \\
\text { family }\end{array}$ & $\begin{array}{c}\text { Friends of the } \\
\text { same age }\end{array}$ & $\begin{array}{c}\text { Parental } \\
\text { Control }\end{array}$ \\
\hline $\begin{array}{c}0.001 \\
\text { Candidate }\end{array}$ & $\begin{array}{c}0.476 \\
\text { No Candidate }\end{array}$ & $\begin{array}{c}0.002 \\
\text { Candidate }\end{array}$ & $\begin{array}{c}0.301 \\
\text { No Candidate }\end{array}$ & $\begin{array}{c}0.013 \\
\text { Candidate }\end{array}$ & $\begin{array}{c}0.410 \\
\text { No Candidate }\end{array}$ \\
\hline
\end{tabular}

Based on Table 3, the girlfriend p value 0.000 was associated with premarital sex behavior in street children and street children who had 39.4 times risky boyfriends for premarital sex behavior compared with street children without boyfriends. Variables of pornographic exposure and peer counfounding influence with girlfriend status variables.

Table 3. The Final Multivariate Modeling

\begin{tabular}{clccc}
\hline No & \multicolumn{1}{c}{ Variabel Independen } & P Value & POR & $(95 \%$ CI $)$ \\
\hline 1 & Girlfriend status & 0.000 & 39.414 & $7.864-197.531$ \\
2 & Pornografy exposure & 0.103 & 0.255 & $0.049-1.319$ \\
3 & Friends of the same age & 0.083 & 2.743 & $0.877-8.576$ \\
\hline
\end{tabular}

Based on the statistical test it can be seen that the variables of girlfriend status, exposure with pornography and peer influence related to prenuptial sex behavior on teenager street children in Pekanbaru City. While the variables of adolescent knowledge about reproductive health, family harmony, parental supervision is not related to Premarital Sex Behavior on Teenage street children. Teenager who has a girlfriend is at risk 39 times for premarital sex behavior compared with teenagers who do not have a girlfriend. Furthermore, a multivariate analysis was conducted to determine the most dominant relationship between 6 research variables. The initial stage of multivariate analysis is the determination of the potential independent variable (multivariate candidate variable) which will be included in the multivariate analysis that is the variable of the bivariate analysis having the value $p \leq 0.25$. Bivariate selection can be seen in Table 2 and analysis of bivariate selection performed, girlfriend status variables, Pornographic Exposure and peers enter into candidates in multivariate modeling because it has $\mathrm{p}$ value $<0.25$. Then do multivariate modeling of the three variables. After the multivariate modeling, the girlfriend's $\mathrm{p}$ value $<0.05$ means that the status of a boyfriend is related to premarital sex behavior in street children and street children who have 39.4 times risky girlfriends for premarital sex behavior compared with street children who do not have a boyfriend. Variables of Pornographic Exposure and peer counfounding influence with girlfriend status variables.

\section{DISCUSSION}

From the research results there is a relationship between the status of boyfriend with teen sex behavior. Street children who have a girlfriend at risk 39, 4 times for premarital sex behavior compared with street children who do not have a boyfriend. Teenagers who are dating have a high enough chance of premarital sexual activity / behavior. The results of this study are in line with the 2012 samino study on Sex Adolescent Sex Behavior of SMAN 14 Bandar lampung 2011 which indicates the relationship between dating status with teen sex behavior with $\mathrm{p}=0.015$. According to Soetjiningsih (2006) Dating means routine meeting with lovers to spill all desires in various ways such as holding hands, looking at each other, hand in hand, kissing, and hugging even sexual relationships [6]. In this study many street children are dating status is seen from the deviant behavior that they do ranging from kissing cheeks, petting, fingering erogan area to sexual intercourse $(65 \%)$. The majority of street children who have a girlfriend are practicing premarital before married with their respective girlfriends. From the results of the study there were 22 teenagers $(22 \%)$ who did not have no girlfriend who had premarital sex while from 78 teenagers who have girlfriend as many as 45 teens $(57,7 \%)$ do premarital sex. This shows the status of a boyfriend is related to premarital sex. Adolescents are currently undergoing drastic changes in their sexual behavior. Nearly $80 \%$ of teenagers have sex before marriage with their girlfriends. The survey results on the sexual behavior of junior and senior high school students in Cianjur, West Java in 2006 showed more than $60 \%$ of 412 students had sexual intercourse [7],[8].

From the results of the study there was no association between pornographic exposure and premarital seks behavior on juvenile street children. This variable is said to be unrelated because there are some adolescents who are exposed to pornography but still many street children who are afraid of sin when 
doing sex behavior before marriage and street children still get supervision from parents such as children monitored and called to schedule home. The results of research in line with research Saputri 2009 states that those who frequently access pornography sites at risk 1.6 times married as compared to adolescents who do not have access to pornography [9]. Remasons with high access to mass media against pornography at risk of premarital sex than adolescents who have never been exposed to pornography. Although street children access porn sites but street children are ventured by masturbation or masturbation so that sexual behavior does not happen [10].

From the results of the study there is no relationship between the Knowledge of Teens about Reproductive Health with teen sex behavior. This variable is said not related because youth knowledge about sex most of the many who know the impact that occurs when sexual intercourse before marriage one of them is the occurrence of disease that attacks the genitals boy and girl. This is in accordance with Salisa research which says that although knowledge of many respondents who know about sexuality but their action is still good because sexual behavior will impact to itself so that like the happening of sexually transmitted disease (PMS) [11]. Therefore, in this study there is no influence between the levels of knowledge of respondents with sexual behavior of respondents. Not necessarily someone who is knowledgeable about sex will behave sexually unfairly before marriage [5]. From the results of the study there is no relationship between Family Harmony with teen sex behavior. This variable is not related because the average street children still have parents so that the child's behavior is always paid attention to his parents. In this case the most influential is the nuclear family. Damage or failure of the future is also influenced by the family [12]. Sexual behavior of a person is not related to the family, but rather to gestures or parental sayings that serve as a real example for the child. It is clear that the greatest demand in the formation of morality is how the parents or family direct and shape it [13].

From the results of the study there is no relationship between peers with teen sex behavior. Teenagers are more out of the house with peers as a group, so it is understandable that peer-peer influences on attitudes, speech, interests, looks and behaviors outweigh the influence of families [14]. Peers also serve as a source of information, an understanding of problem solving, and as a place to express themselves. In this study, street adolescents are more likely to discuss / discuss reproductive health problems with their peers than teachers or their parents. Peer groups have a function as a place to conduct trial and error, a place for freedom from parents [15].

From the results of the study there is no relationship between parental controls with teen sex behavior. In this study, juvenile street children also get supervision from their parents. One of them advised to keep themselves when mixing with the opposite sex. According to Faridah, the role of parents in educating their children is very decisive character formation and development of children's personality. Good communication channels between parents and children can create an atmosphere of mutual understanding of various types of family problems, especially about adolescent problems. This condition will affect to the attitudes and behaviors that the child will bring in according to their parents' values [10],[16].

Parents play a very important role to improve knowledge of adolescents in general and reproductive health in particular. In turn, adolescent knowledge of reproductive health may prevent them from premarital sexual intercourse and risky sexual intercourse [17],[18]. However, this study described there is no significant relationship between the role of parents with premarital sexual behavior.

\section{CONCLUSION}

There is a significant relationship between boy/girlfriends with premarital sex on the adolescent children of city streets Pekanbaru. There is no relationship of knowledge, exposure of pornography, family harmony, peers and parental supervision with premarital sex on the adolescent children of city streets Pekanbaru. The need for counseling teenagers, especially adolescents who are exposed to pornography so that they do not access pornography anymore by providing busy or useful activities so that they do not have time for acts of access to pornography so that sex behavior before marriage can be avoided.

\section{REFERENCES}

[1] Oktaria Y. and Pardede K., "Self-concept of Street Children Teenagers," J Psikol, vol/issue: 1(100), pp. 146-51, 2008.

[2] P. P. W. Kumalasari, "Self-concept of Street Children Teenagers in Central Semarang," The journal nursing soul, vol. 1, 2013.

[3] Maryatun, "Premarital Sexual Behavior Studies in Teens."

[4] Karyati S., "Social environment, peers, spirituality and premarital sexual behavior of street adolescents," Urecol Proceeding, pp. 1418-25, 2017.

[5] Lusi R., "Factors that deals with knowledge of free sex in adolescents in high school tri bakti the city of 
pekanbaru," 2013.

[6] Soetjiningsih, "Growing Youth and Problems," Are sprouting youth and the problem, vol/issue: 1(2), pp. 59, 2004.

[7] Setiawati D., "Youth Perceptions About Sex Education: Qualitative Descriptive Study on High School Students 4 Magelang," 2010.

[8] Setiawan R. and Nurhidayah S., "The effect of courtship on premarital sex behavior," J Soul., vol/issue: 1(2), pp. 59-72, 2008.

[9] Saputri N., "Adolescents and premarital sex," J Sociol., vol/issue: 1(1).

[10] Susanti, "Sexual General Relationship, Media Exposure And Effect Of Friends By Sexual Adolescent Behavior In SMPN 6 Palolo Sulawesi Tengun Year 2012," 2012.

[11] Salisa A., "Premarital sex behavior among adolescents (Qualitative Descriptive Study About Prenuptial Sex Behavior Among Youth Surakarta)," 2010. https://eprints.uns.ac.id/10458/

[12] Setyadani A. S., "Reproductive Health Behavior in Street Children With Active Sex In Semarang City," J Kesehat Masy, vol/issue: 9(1), pp. 30-6, 2013.

[13] Faridah U. and Charmenita N., "Role and Communication of Parents With Sexual Behavior of Children in Holy Demand," vol/issue: 8(2), pp. 39-43, 2017.

[14] Hurlock E. "Adolescent development," mc graw-hill, 2004.

[15] Santrock J., “Adolescence : The development of teenagers,” Erlangga, 2007.

[16] E. S. Nihayah and Legowo M., "Exploitation of Children (Case Study On Street Children in Surabaya)," Paradigma, vol/issue: 4(1), pp. 1-9, 2016.

[17] Suhartini T. and Panjaitan N., "Strategy to Survive Street Children," vol/issue: 3(2), pp. 215-30, 2009.

[18] Y. R. Dwijayanti and Herdiana I., "Sexual behavior a street kid in review with the theory health belief a model (hbm)," Insan, vol. 13, 2011. 